\title{
Has Continued Exposure to Banana Xanthomonas Wilt Worsened Farmers' Welfare Over Time? Evidence From Banana-Producing Households in Uganda
}

\author{
Esther Gloria Mbabazi ${ }^{1}$, Enoch M. Kikulwe ${ }^{1}$, Joseph Lule Kyanjo ${ }^{2}$, Nasser Mulumba ${ }^{2}$, \\ Edward Kato ${ }^{3}$ \& Elisabetta Gotor ${ }^{4}$ \\ ${ }^{1}$ Bioversity International, Kampala, Uganda \\ ${ }^{2}$ Makerere University, Kampala, Uganda \\ ${ }^{3}$ IFPRI, Washington DC, USA \\ ${ }^{4}$ Bioversity International, Rome, Italy \\ Correspondence: Esther Gloria Mbabazi, Bioversity International, P.O. Box 24384, Kampala, Uganda. Email: \\ e.g.mbabazi@cgiar.org
}

Received: June 29, 2021

Accepted: August 31, 2021

Online Published: October 15, 2021

doi:10.5539/jas.v13n11p11

URL: https://doi.org/10.5539/jas.v13n11p11

The research is financed by the CGIAR Research Program (CRP) Roots, Tubers and Bananas (RTB).

\begin{abstract}
The livelihoods of millions of banana-farming households have been affected by Banana Xanthomonas Wilt (BXW) in Uganda for nearly two decades. The disease has no known cure, all banana cultivars grown are susceptible to it and it is endemic in all banana-producing regions in the country. This study analysed the long-term impact of the disease on the livelihoods of banana-producing households. Using a balanced panel dataset of 1,056 households, which were visited in 2015 and revisited in 2018, provides the opportunity to empirically measure the long-term consequences of the disease on farmers' economic wellbeing in the four major banana growing regions in Uganda. We find striking results pertinent to disease incidence, success in disease management, household income and poverty when deploying BXW control practices. Although the disease has remained present in farmers' fields, there is a significant reduction in household poverty levels. Results show that some farmers expanded the production of beans and coffee without encroaching on their banana plantations. Increase in bean production was largely through intercropping. Investment in coffee was constrained by land ownership, hence only a viable venture for the wealthy farmers who own bigger pieces of land. Land-poor farmers continued to rely on bananas for their livelihoods. Consistent participation in disease management training significantly influenced adoption of the cultural control practices. Consequently, farming households that systematically adopted these practices were able to maintain low levels of disease incidence, improve productivity by $438 \mathrm{~kg} / \mathrm{ha} / \mathrm{year}$ and increased their daily and annual household income by US\$1.75 and UGX 2.383 million (US\$648), respectively. The findings suggest that banana is an important crop to smallholder farmers and expansion into other cash crops requires bigger resource outlays, and that despite continued exposure to BXW, farmers' income increased over time. Farmers should continuously and systematically use the recommended control practices to avoid BXW resurgence and, consequently, a reduction in their income.
\end{abstract}

Keywords: Banana Xanthomonas Wilt, coping strategies, household income, systematic adoption

\section{Introduction}

About a third of the global banana production is conducted in Sub-Saharan Africa (SSA) where the crop is a very important staple and a cheap source of minerals and vitamins, particularly vitamins A, C and B6 (Karamura et al., 2008). In East and Central Africa (ECA), the banana crop significantly contributes to household food security and income of the farming communities (Muchuruza \& Melchior, 2013; Nkuba et al., 2015; Ocimati et al., 2019). Besides being the leading banana producer in ECA, Uganda has the highest per capita consumption of bananas in the world (Kabahenda \& Kapiriri, 2010; Kikulwe, Okurut, Ajambo, Nowakunda, et al., 2018; Kilimo Trust, 2012). The crop accounts for $17 \%$ of daily caloric needs in the country (Fiedler, Kikulwe, \& Birol, 2013) and is the major 
income source for millions of farmers (Jogo, Karamura, Tinzaara, Kubiriba, \& Rietveld, 2013; Karamura et al., 2010; Kikulwe et al., 2018). Furthermore, it has great environmental value in most farming systems as it reduces soil erosion on steep slopes, conserves soil fertility and provides cover to other crops such as beans, groundnuts and coffee with which it is often intercropped (Geberewold, 2019; Uwamahoro, Berlin, Bylund, Bucagu, \& Yuen, 2019).

Despite its importance, the banana crop is affected by Banana Xanthomonas Wilt (BXW) disease-the leading impediment to its production in ECA (Nkuba et al., 2015). It has no cure and all the cultivars grown in SSA are susceptible to it (Kubiriba \& Tushemereirwe, 2014). In 2001, banana farms in Uganda were hit by the BXW epidemic (Tushemereirwe et al., 2004). The disease spread at such an alarming rate that, by 2005 , more than $76 \%$ of the fields in the key growing regions were affected (Tushemereiwe et al., 2006). The epidemic resulted in drastic losses, since every mat with a stem that exhibited symptoms had to be uprooted and buried (Tripathi et al., 2009). Kalyebara et al. (2006) estimated that, if the disease was left to spread uncontrolled, Uganda stood to lose US\$295 million per annum in revenue from banana output, valued at farm gate prices. Similarly, Kayobyo, Aliguma, Omiat, Mugisha, and Benin (2005) noted that uncontrolled BXW can spread at an infection rate of $8 \%$ per annum in cooking bananas, resulting in a total production loss of 56\% over a 10 -year period. Karamura et al. (2010) found that the total yield loss due to BXW at the peak of the epidemic between 2001 and 2004 was between 30-52\% leading to a decline in banana harvests, sales, farm-gate prices and total household income.

Farmers resorted to different coping strategies to deal with the BXW outbreak, some of which negatively affected banana production and productivity. For instance, farmers in the Kagera basin of Rwanda, Tanzania and Burundi were prompted to diversify into other food crops such as maize, cassava and sweet potato, which led to a reduction in the area under banana (Nkuba et al., 2015). Similarly, after losing about $80 \%$ of their bananas within a two-year period, farmers in Katana village around Lake Kivu in the Democratic Republic of Congo cleared their plantations to make way for other crops (Vezina, 2014). In Uganda, the households whose plantations were infected with BXW reduced consumption of own-produced bananas and resorted to consuming and trading more of the other food crops (Karamura et al., 2010). A few of these households (9\%) reported clearing the plots and planting similar or different banana cultivars, or different crops, whereas only 5\% reported complete abandonment of banana (Karamura et al., 2010).

To curtail the spread of BXW, a set of cultural control practices are recommended. These practices include planting healthy suckers, breaking of male buds with a forked stick, disinfecting farm tools after use on each plant and removal of each infected plant also referred to as single diseased stem removal (Blomme et al., 2017; Jogo et al., 2013; Kikulwe et al., 2019). These cultural practices reduce the inoculum's density and limit the spread of the pathogens but must be applied as a package for effective disease control (Blomme et al., 2017; Kubiriba \& Tushemereirwe, 2014). However, since more than $90 \%$ of the farmers in ECA use suckers from their own fields or rely on farmer- to-farmer exchanges, as opposed to pathogen-free tissue culture plantlets that are expensive and not readily accessible, they have no means to ascertain whether the suckers used are disease-free (Jogo et al., 2013; Smith, Jones, Karamura, Blomme, \& Turyagyenda, 2008). Based on this evidence, the recommended package of three practices abbreviated as BCC (Breaking the male bud using a forked stick; Cleaning tools through disinfection, and Cutting down diseased stems) has been widely promoted and adopted (Blomme et al., 2017; Jogo et al., 2013). Adoption of this package has been found to significantly increase banana productivity and sales (Kikulwe et al., 2019). Male buds are the primary site for insect-mediated infection, hence their removal using a forked stick helps to control the disease (Biruma et al., 2007). Disinfecting farm tools using sodium hypochlorite or flaming them over a fire kills any pathogens that may remain on the tools after working on a diseased plant, preventing transmission from one plant to another (Mwangi, Nakato, \& Muthoni, 2007). On the other hand, single diseased stem removal (SDSR) reduces disease inoculum and its correct implementation has been found to reduce BXW incidence from $80 \%$ to less than 2\% within 3-4 months (Blomme et al., 2017). SDSR is also highly recommended because it is a labour-saving and cost-effective practice (Blomme et al., 2019; Kubiriba \& Tushemereirwe, 2014).

Literature is replete on the adoption of these cultural control practices and the management of BXW in the region. Some scholars have assessed the role of specific control practices in curbing the disease (Blomme et al., 2014; Blomme et al., 2017; Mwangi et al., 2007; Nakakawa et al., 2017). Kikulwe et al. (2018) examined the role of gender in management of the disease, whereas Ocimati et al. (2019) cited the key factors responsible for disease spread and mapped the current hotspots and vulnerable landscapes, which is crucial for disease early warning and management to curtail further spread. Some studies have focused on the determinants of adoption of the control practices (Jogo et al., 2013; Kikulwe et al., 2019) and the approaches used to promote these practices (Kubiriba \& Tushemereirwe, 2014). A handful of studies (Karamura et al., 2010; Kikulwe et al., 2019) have assessed the effects 
of BXW and adoption of control practices on the livelihoods of farmers in Uganda. Kikulwe et al. (2019) analysed the impacts of adoption on banana productivity and sales using augmented inverse probability weighting based on cross-sectional data. Yet, Karamura et al. (2010) assessed the impact of BXW on banana yield and livelihoods of farming households using data for two distinct periods (2001 and 2004) from four districts in central Uganda, which is not representative of the four banana growing regions in Uganda. We contribute to this literature by measuring the impact of systematic adoption of the control practices on banana productivity and household welfare. According to Nakakawa et al. (2017), effective management of BXW requires systematic adoption of control practices to avoid a possible resurgence of the disease. We used a balanced panel dataset of 1,056 farming households from four major banana-producing regions in Uganda and employed an Ordinary Least Squares (OLS) method to provide in-depth evidence on the long-term impact of BXW, and systematic adoption of the control practices on farmers' income and the coping strategies they employed amidst continued exposure to the disease.

The remainder of the paper is arranged as follows: the next section describes the methods and data used for the study. Section three presents and discusses empirical findings. The final section draws the concluding remarks.

\section{Materials and Methods}

\subsection{Sampling and Sample Size}

The data used was collected from the four major banana producing regions in Uganda namely: south-western, central, mid-western and eastern. Two rounds of household surveys were conducted, one in 2015 and the other in 2018 from 1,056 randomly selected banana-farming households constituting a balanced panel with 2,112 observations. Details of sampling and sample size determination are found in Kikulwe et al. (2019). The 2015 data served as the baseline. In both survey rounds (2015 and 2018), face-to-face interviews were conducted using a structured questionnaire to collect data on: socio-demographic characteristics of the farmer; status of BXW at individual farm level; BXW control practices adopted by the farmer to manage the disease; number of years since BXW was first observed on the farm; production details of banana and the other major crops grown; income from livestock; and income from off-farm activities.

\subsection{Analytical Methods}

\subsubsection{Empirical Approach to Determine the Drivers of Households' Choice of Coping Strategy in the Face of} Continued BXW Exposure

Exposure to BXW significantly affects households' welfare (Karamura et al., 2010; Kikulwe et al., 2019). Like any other shock, the level of impact of the shock depends on the level of exposure (in this case incidence of BXW) and level of household endowments such as land owned, skills and knowledge of how to deal with the shocks (Chapoto \& Jayne, 2008; Mehar, Mittal, \& Prasad, 2016). These factors determine the type of coping strategy adopted by the household and overall household welfare. We therefore first examine the drivers of the type of coping strategy employed by households amidst continued presence of BXW on banana farms. Six coping strategies are evaluated. Three of the six coping strategies (i.e., change in maize, beans, and coffee acreages) focus on expected changes in crop mix land reallocation strategies to deal with the disease shock. Two other strategies (i.e., livestock income and off-farm income) focus on diversification into other income sources to deal with the disease shock. The last coping strategy is the change in per capita consumption of banana. Similar coping strategies have been examined in the face of various shocks such as climate change (Mehar et al., 2016), human diseases (Chapoto \& Jayne, 2008), and plant diseases (Karamura et al., 2010; T.-T. Nguyen, T. T. Nguyen, \& Grote, 2020; Nkuba et al., 2015).

To determine the choice of coping strategies that households employ to mitigate the effects of BXW disease on household welfare, we used the Ordinary Least Squares (OLS) method. The OLS method has been widely used to examine welfare impacts (Chapoto \& Jayne, 2008; Hartje, Bühler, \& Grote, 2018; Jena, Chichaibelu, Stellmacher, \& Grote, 2012; T.-T. Nguyen, T. T. Nguyen, \& Grote, 2020) including those resulting from plant pests and diseases (T.-T. Nguyen, T. T. Nguyen, \& Grote, 2020). We specified the OLS regressions for each year as follows:

$$
\begin{gathered}
Y_{i t}=\alpha_{1}+\beta_{1} D_{i t}+\theta_{1} H_{i t}+\varepsilon_{i t} i \\
Y_{i(t+3)}=\alpha_{2}+\beta_{2} D_{i(t+3)}+\theta_{2} H_{i(t+3)}+\varepsilon_{i(t+3)}
\end{gathered}
$$

Equations 1 and 2 correspond to 2015 (time $t$ ) and 2018, (time $t+3$ ) respectively. $Y_{i}$ denotes the outcomes for each household i; $D_{i t}$ and $D_{i(t+3)}$ denote the incidence of BXW for household i in 2015 and 2018, respectively, whereas $\mathrm{H}_{\mathrm{i}}$ is a vector of household socioeconomic characteristics and $\varepsilon_{i}$ is a random error term.

To obtain the changes in the outcomes resulting from the changes in disease incidence over time, we take the difference in the variables in the two time periods as shown in Equation 3:

$$
\Delta Y_{i}=Y_{i(t+3)}-Y_{i t}
$$


The socioeconomic characteristics considered, such as gender and education level of the household head, membership in savings groups, and farm location and size, hardly changed in the study period while others like the household's age are changing by a constant. Therefore, to avoid endogeneity issues, we take these variables at baseline as in 2015 (Wooldridge, 2002). Thus, the regression equation is specified as follows:

$$
\Delta Y_{i j}=\alpha+\beta \Delta D_{i}+\emptyset_{1} \Delta W_{i t}+\partial_{1} R_{i}+\theta_{1} H_{i t}+\Delta \varepsilon_{i}
$$

Where, $\Delta Y_{i j}$ is the 2018-2015 difference for a coping strategy $\mathrm{j}$, for each household i. $\Delta Y_{i 1}$ is the difference in acreage allocated to maize, $\Delta Y_{i 2}$ is the difference in acreage allocated to beans, $\Delta Y_{i 3}$ is the difference in acreage allocated to coffee, $\Delta Y_{i 4}$ is the difference in per capita banana consumption, $\Delta Y_{i 5}$ is the difference in household livestock income, and $\Delta Y_{i 6}$ is the difference in household off-farm income. $D_{i}$ is the disease incidence indicator, $\beta$ is the effect of the disease incidence on the coping strategy adopted, $\alpha$ is a constant, $H_{i t}$ is a vector of socioeconomic household characteristics and location variables as captured in 2015 with their corresponding effects captured as $\theta_{1}$. The socioeconomic household characteristics included in the model estimations were age, sex, and education level of the household head, household size, land owned and membership to a SACCO. $\Delta W_{i t}$ is the difference in number of disease control practices adopted and $R_{i}$ is a location variable captured by the region of the household. $\Delta \varepsilon_{i}$ is the difference between errors in 2018 and 2015.

\subsubsection{Empirical Approach for the Impact of BXW on Farmers' Welfare}

The OLS method was also used to estimate the impact of BXW on farmer' welfare as shown in Equation 5.

$$
\Delta Z_{i j}=\alpha+\beta \Delta D_{i}+\emptyset_{1} \Delta W_{i t}+\partial_{1} R_{i}+\theta_{1} H_{i t}+\partial_{1} E_{i}+\partial_{1} P_{i}+\partial_{1} T_{i}+\partial_{1} S_{i}+\Delta \varepsilon_{i}
$$

Where, $\Delta Z_{i j}$ is the 2018-2015 difference for a welfare variable $j$, for each household i. $\Delta Z_{i 1}$ is the difference in banana productivity (ton/ha/year), $\Delta Z_{i 2}$ is the difference in daily household Welfare, $\Delta Z_{i 3}$ is the difference in Annual Household welfare. $\Delta D_{i}, \Delta W_{i t}, R_{i}, H_{i t}$ and $\Delta \varepsilon_{i}$ are as already defined in Equation $4 . E_{i}$ is the number of years the household has been exposed to BXW, $P_{i}$ is a dummy variable that captures whether BXW was present on the farm by the time of the survey in 2018, $T_{i}$ is a dummy variable for households that received training in management of BXW in both panels, and $S_{i}$ is a dummy variable for households that adopted sanitation practices in both panels.

\subsection{Variables Used}

In this study, disease incidence was measured as the difference between the number of mats infected with BXW per acre on each farm in 2018 and 2015 at the point of data collection. This measure is used as the treatment variable in all models. We therefore hypothesize that, with increased incidence, farmers are more likely to employ coping mechanisms such as increasing the production of other crops, reducing consumption of bananas and/or engaging in other income-generating projects such as livestock production or off-farm activities.

Household welfare is measured as the aggregated value in Uganda shillings (UGX) of the value of production of four major crops (banana, maize, beans and coffee) grown, income from livestock sales and household off-farm income obtained over a period of one year. Off-farm income includes the wages, salaries and pensions of all household members, land rents and capital earnings, as well as any net profit (revenue minus cost) from non-agricultural businesses. A description of the welfare variable is shown in Table 1. Banana productivity affects food security and it influences the overall wellbeing of the household. BXW is expected to have a negative effect on banana productivity (Blomme et al., 2014; Karamura et al., 2010). Per capita consumption of bananas is another outcome variable that was considered, and it is measured as the total kilograms of bananas consumed per household member per year. As a result of the disease, per capita consumption of bananas is also expected to decline as the farming households feed more on other foods and less on bananas (Karamura et al., 2010). 
Table 1. Description of the welfare variable

\begin{tabular}{ll}
\hline Component of Household Welfare & Detailed Description \\
\hline Annual value of crop production* & $\bullet \quad$ Value of banana produced \\
& $\bullet \quad$ Value of maize produced \\
& $-\quad$ Value of beans produced \\
\hline Annual livestock sales & Value of coffee produced \\
Annual household off-farm income & $\quad$ Wages, salaries, and pensions \\
& $-\quad$ Land rents and capital earnings \\
\hline Annual household welfare & Net profit from non-agricultural businesses \\
\hline Daily household welfare & Summation of all the above
\end{tabular}

Note. $*$ The value of crop production is obtained by multiplying the volume of crop produced by the average prevailing price per unit.

Most monetary values are expressed in Uganda shillings (UGX), except for daily household welfare that is expressed in US\$ for ease of comparison with global poverty levels ( 1 US $\$=3,677$ UGX). To account for inflation and make monetary values comparable for the two survey rounds, 2015 data were adjusted to 2018 using the official consumer price index as quoted by the Uganda Bureau of Statistics (UBOS, 2019).

For most of the regression models, the same vector of covariates is used, although other explanatory variables are sometimes added depending on the particular outcome. The vector of covariates includes household characteristics, such as age, education and gender of the household head, as well as the size of the household, social aspects such as membership in a SACCO (Savings and Credit Co-operative), farm characteristics such as total land owned, and the level of adoption of the BXW control practices. In this paper, we are not measuring adoption per se because it has been extensively explored in various studies (Bagamba et al., 2006; Jogo et al., 2013; Karamura et al., 2010; Kikulwe et al., 2018, 2019; Kubiriba \& Tushemereirwe, 2014). We are focusing on the systematic adoption of these practices as opposed to conducting them sporadically. Recent research has revealed that for effective BXW management, adoption needs to be systematic and consistent, even when the disease is undetectable, to eliminate possible resurgence (Nakakawa et al., 2017).

\section{Results and Discussion}

3.1 Changes and Trends in Area Allocated to Each Crop, Production and Poverty Between 2015 and 2018

In this section, we present the descriptive statistics, changes, and trends in the area planted to each crop, production, and poverty between 2015 and 2018 (Table 2). 
Table 2. Descriptive statistics of dependent and explanatory variables

\begin{tabular}{|c|c|c|c|c|c|}
\hline \multirow{2}{*}{ Variable } & \multicolumn{2}{|r|}{2015} & \multicolumn{2}{|r|}{2018} & \multirow{2}{*}{$\mathrm{t}$ value } \\
\hline & $\mathrm{n}$ & mean & $\mathrm{n}$ & mean & \\
\hline Age of the household head & 1056 & $53.8(14.5)$ & 1056 & $56.7(14.6)$ & $-4.65 * * *$ \\
\hline Gender of the household head ( $1=$ Male $)$ & 1056 & $0.75(0.43)$ & 1056 & $0.74(0.44)$ & 0.75 \\
\hline Education level of household head (years) & 1056 & $5.95(3.91)$ & 1056 & $5.95(3.91)$ & 0 \\
\hline Household size & 1056 & $6.37(3.13)$ & 1056 & $6.37(3.14)$ & 0.05 \\
\hline Membership in a SACCO (1=Yes) & 1056 & $0.23(0.42)$ & 1056 & $0.29(0.45)$ & $-2.75 * * *$ \\
\hline Presence of BXW (1=Yes) & 1056 & $0.63(0.48)$ & 1056 & $0.56(0.50)$ & $3.45^{* * *}$ \\
\hline Number of adopted practices & 1056 & $1.46(1.06)$ & 1056 & $1.90(1.03)$ & $9.70 * * *$ \\
\hline Sanitation practices employed ( $1=$ Yes $)$ & 1056 & $0.84(0.37)$ & 1056 & $0.76(0.43)$ & $4.5^{* * *}$ \\
\hline Banana acreage & 1020 & $2.64(3.33)$ & 1051 & $2.52(2.95)$ & 0.931 \\
\hline Maize acreage & 441 & $1.21(1.48)$ & 809 & $1.50(1.88)$ & $-2.787 * * *$ \\
\hline Beans acreage & 616 & $0.65(0.74)$ & 933 & $1.10(1.25)$ & $-7.999 * * *$ \\
\hline Coffee acreage & 458 & $2.27(2.41)$ & 745 & $1.85(2.55)$ & $2.826 * * *$ \\
\hline Disease incidence (mats infected per acre) & 625 & $4.14(5.22)$ & 587 & $4.32(5.59)$ & -0.577 \\
\hline Value of banana production to value of crop production & 886 & $0.70(0.32)$ & 965 & $0.83(0.20)$ & $-10.550 * * *$ \\
\hline Value of banana production to household income & 886 & $0.49(0.34)$ & 965 & $0.72(0.25)$ & $-16.849 * * *$ \\
\hline Poor ( $1=$ Less than $\$ 1.90$ per day, $0=$ otherwise $)$ & 1056 & $0.55(0.50)$ & 1056 & $0.19(0.39)$ & $18.331 * * *$ \\
\hline Extremely poor $(1=$ Less than $\$ 1.00$ per day, $0=$ otherwise $)$ & 1056 & $0.36(0.48)$ & 1056 & $0.11(0.31)$ & $14.176^{* * *}$ \\
\hline
\end{tabular}

Note. Values in parentheses are standard deviations. $* * * p<0.01,{ }^{* *} \mathrm{p}<0.05,{ }^{*} \mathrm{p}<0.1$.

Descriptive statistics of changes in the key variables in 2015 and 2018 are summarised in Table 2. Despite a significant increase in the land allocated to maize, beans and coffee, there was no significant change in the land allocated to bananas. However, the contribution of bananas to the total value of crop production and to household welfare increased significantly in 2018, showing a high concentration of earnings among the interviewed farmers. The number of farms that had traces of BXW significantly reduced from $63 \%$ in 2015 to $56 \%$ by 2018 and on average, there were approximately 4 mats infected per acre in both time periods. There was a significant increase in the average number of practices adopted from one to two. It is evident that disease incidence was maintained at low levels through continued adoption of the control practices. BXW has been found to resurge where the levels of adoption of the control practices are low (Jogo et al., 2013; Kikulwe et al., 2019). Globally, households surviving on less than US\$1.90 per day are categorised as poor, whereas the official absolute poverty line for Uganda - as for other low-income countries - is at US\$1.0 per day (Ssewanyana \& Kasirye, 2013; UBOS, 2014; World Bank, 2008). For our analysis, we categorised those living below US $\$ 1.00$ per day as extremely poor. We observed a significant reduction in the poverty levels, which implies that the farming households have not been thrown into abject poverty despite continued exposure to BXW.

\subsection{Empirical Results}

\subsubsection{Coping Strategies}

This section summarises the coping strategies that banana-producing households employed in the face of BXW. Table 3 shows the empirical results for the models used to evaluate the impact of BXW on land allocated to maize, beans and coffee; per capita consumption of banana, livestock sales and involvement in off-farm activities following Equation 4. 
Table 3. How changes in BXW incidence influenced changes in maize, bean and coffee acreages; per capita consumption of banana; income from livestock and off-farm activities

\begin{tabular}{|c|c|c|c|c|c|c|}
\hline Parameters measured & Maize acreage & Beans acreage & Coffee acreage & $\begin{array}{l}\text { Per capita } \\
\text { consumption }\end{array}$ & $\begin{array}{l}\text { Livestock } \\
\text { income }\end{array}$ & $\begin{array}{l}\text { Off-farm } \\
\text { income }\end{array}$ \\
\hline Change in No. mats infected & $0.004(0.004)$ & $0.012 * *(0.006)$ & $0.041^{* *}(0.019)$ & $0.037(0.238)$ & $0.001(0.005)$ & $-0.003(0.015)$ \\
\hline South-western vs Central & $-0.292(0.335)$ & $-0.729(0.573)$ & $0.879(0.633)$ & $2.471(9.518)$ & $0.476(0.533)$ & $1.164(1.055)$ \\
\hline Mid-west vs Central & $0.036(0.207)$ & $-0.626(0.572)$ & $-0.658(0.621)$ & $-25.596^{* *}(10.129)$ & $0.381(0.391)$ & $0.487(1.202)$ \\
\hline Eastern vs Central & $0.064(0.220)$ & $-0.488(0.508)$ & $0.491(0.445)$ & $-39.591 * * *(10.896)$ & $-0.052(0.402)$ & $1.664(1.188)$ \\
\hline SACCO Membership $(1=$ yes; $0=$ no $)$ & $0.003(0.252)$ & $0.311 *(0.174)$ & $0.453(0.580)$ & $9.111(7.728)$ & $0.079(0.406)$ & $-0.234(0.589)$ \\
\hline Age of household head & $-0.003(0.004)$ & $-0.016(0.014)$ & $-0.004(0.011)$ & $-0.043(0.241)$ & $0.013(0.014)$ & $0.033 *(0.019)$ \\
\hline Male household head & $0.259 *(0.135)$ & $-0.729(0.476)$ & $0.244(0.396)$ & $8.071(8.020)$ & $0.105(0.208)$ & $-0.991 * *(0.502)$ \\
\hline Education of household head (years) & $0.022(0.014)$ & $-0.011(0.049)$ & $-0.015(0.062)$ & $1.006(0.908)$ & $0.046(0.056)$ & $0.014(0.068)$ \\
\hline Household size & $0.084 * * *(0.021)$ & $0.064(0.041)$ & $0.003(0.112)$ & $1.023(1.064)$ & $0.120 * *(0.060)$ & $0.177(0.154)$ \\
\hline Total land owned (acres) & $0.015(0.008)$ & $0.000(0.005)$ & $0.038^{* *}(0.018)$ & $0.381(0.322)$ & $-0.016(0.020)$ & $-0.049(0.041)$ \\
\hline No. of adopted practices & $0.133^{* *}(0.058)$ & $0.228 * * *(0.084)$ & $0.029(0.367)$ & $-22.594 * * *(3.393)$ & $0.255 * * *(0.092)$ & $0.290(0.248)$ \\
\hline Constant & $-0.171(0.331)$ & $1.895(1.972)$ & $-0.583(1.200)$ & $30.538(19.764)$ & $-2.036^{*}(1.212)$ & $-3.830 * *(1.807)$ \\
\hline No. of observations & 1002 & 1002 & 448 & 949 & 1002 & 1002 \\
\hline R-squared & 0.016 & 0.018 & 0.033 & 0.065 & 0.012 & 0.012 \\
\hline F-value & $4.80 * * *$ & $2.09 * *$ & $1.98 * *$ & $5.88 * * *$ & $2.30^{* * *}$ & 1.48 \\
\hline
\end{tabular}

Note. Estimation coefficients are shown with standard errors in parentheses. ${ }^{* * *} \mathrm{p}<0.01,{ }^{*} \mathrm{p}<0.05,{ }^{*} \mathrm{p}<0.1$. $\mathrm{SACCO}=$ Savings and Credit Cooperative.

Farmers employ different strategies in response to BXW, but resource reallocation and crop choices are key coping strategies (Karamura et al., 2010; Nkuba et al., 2015). Our results show that with continued exposure to BXW, farmers significantly increased the production of beans and coffee by 0.01 and 0.04 acres, respectively. However, only those with vast pieces of land were able to expand into coffee production. Land size is a measure of wealth, especially among rural households (Elias, Nohmi, Yasunobu, \& Ishida, 2016; Jogo et al., 2013), and ownership of a large farm enables the farmer to engage in other income-generating crop enterprises such as coffee (Jogo et al., 2013). Thus, for the resource-poor farmers to invest in coffee they would have to give up banana cultivation, which is unlikely since they rely on the crop for both food and income (Bagamba et al., 2006). Furthermore, we did not observe a significant decline in banana acreage (Table 2), therefore expanding production of other crops did not necessarily involve displacement of bananas. Previous research indicates similar findings, whereby some of the households affected by BXW cleared their plots and planted similar or different banana cultivars while diversifying into other crops, whereas only five percent reported abandonment of banana production (Karamura et al., 2010).

Implementation of control practices is labour intensive. Although consistent participation in disease management training significantly influenced adoption of the cultural control practices, we also find that the control practices are more frequently applied in larger households that have more family members.

Survey data indicate that the larger families expanded into maize production and adopted the control practices, both of which are labour-intensive ventures, indicating that these households possibly utilize readily available family labour. On the other hand, households that allocated more land to the production of beans also adopted the control practices because beans and bananas are complementary crops and they are usually grown together (Uwamahoro et al., 2019). Households in the central region consume more bananas per capita compared to those in other regions. This is because bananas are largely consumed in the urban and peri-urban areas that are concentrated in the central region. Our findings also show that adoption of the control practices does not translate into increased per capita consumption of bananas. This may be so because the crop is a major income source for these farmers, so they increase sales instead. Our findings align with Kikulwe et al. (2019) who observed that the annual value of banana sales increased significantly with the adoption of more disease control practices.

The households that diversified into livestock production were mostly those with larger families. It is likely that they also adopted the disease control practices because they had family labour available to implement the practices as well as attend to their flock. Generally, gender of the household head did not have a significant effect on the coping strategies that households adopted, except for off-farm activities. Female-headed households ventured more into these activities as a coping mechanism than the male-headed households. These results concur with 
Kikulwe, Okurut, Ajambo, Gotor, et al. (2018) who asserted that female-headed households have limited resource endowments to enable them cope with shocks like BXW outbreaks therefore they may opt for income generating activities off-farm as a coping strategy.

\subsubsection{Impact of BXW on Farmers' Welfare}

The results of the impact of BXW on farmers' livelihoods are shown in Table 4. Although the disease did not have a significant impact on farmers' welfare over time, its presence on the farm led to a significant decline in productivity amounting to $799 \mathrm{~kg} / \mathrm{ha} /$ year, which is about a third of the decline $(2,317.8 \mathrm{~kg} / \mathrm{ha} /$ year $)$ observed in the first four years after the onset of the disease in 2001 (Karamura et al., 2010). The yield losses at the onset of the epidemic in the early 2000 s were much higher partly because there was limited understanding of the epidemiology of the disease (Blomme et al., 2014) and a fairly low rate of adoption of the control practices (Bagamba et al., 2006). Preventing resurgence and the drastic effects of the disease is therefore critical and strongly depends on sustained adoption of the control practices that keep the disease incidence at manageable levels (Nakakawa et al., 2017). Our results show that systematic adoption of the control practices had a positive and significant impact on productivity and household welfare. Each additional practice adopted systematically increased productivity by 438 $\mathrm{kg} / \mathrm{ha} / \mathrm{year}$, as well as daily and annual household welfare by US\$1.75 and UGX 2.383 million (US\$648), respectively ceteris paribus. Therefore, through consistent adoption of the control practices, the farming households' economic wellbeing has improved despite the continued exposure to BXW.

Table 4. Impact of Banana Xanthomonas Wilt (BXW) on banana productivity, daily and annual household welfare

\begin{tabular}{|c|c|c|c|}
\hline & $\begin{array}{l}\text { Banana productivity } \\
\text { (ton/ha/year) }\end{array}$ & $\begin{array}{l}\text { Daily Household Welfare } \\
\text { (USD) } \dagger\end{array}$ & $\begin{array}{l}\text { Annual Household Welfare } \\
\text { (million UGX) }\end{array}$ \\
\hline Change in No. mats infected & $0.012(0.011)$ & $0.024(0.031)$ & $0.034(0.043)$ \\
\hline SACCO Membership $1=$ yes; $0=$ otherwise) & $0.200(0.526)$ & $1.547(1.106)$ & $2.104(1.504)$ \\
\hline Age of household head (years) & $0.029(0.029)$ & $-0.015(0.033)$ & $-0.020(0.045)$ \\
\hline Male household head & $0.490(0.816)$ & $0.966(0.969)$ & $1.316(1.317)$ \\
\hline Education of household head (years) & $0.036(0.099)$ & $0.421 * * *(0.124)$ & $0.573^{* * *}(0.169)$ \\
\hline Household size & $-0.039(0.083)$ & $0.364 * * *(0.135)$ & $0.495^{* * *}(0.180)$ \\
\hline Total land owned (acres) & $0.042 * *(0.020)$ & $0.169 *(0.092)$ & $0.230(0.104)$ \\
\hline No. of practices adopted systematically & $0.653^{* *}(0.315)$ & $1.753 * * *(0.469)$ & $2.383 * * *(0.637)$ \\
\hline BXW exposure (years) & $-0.081(0.064)$ & & \\
\hline BXW present $(1=$ Yes, $0=$ otherwise $)$ & $-1.309 * *(0.653)$ & & \\
\hline Consistent BXW training ( $1=\mathrm{yes}, 0=$ otherwise $)$ & $2.614 * * *(0.770)$ & $9.494 * * *(1.992)$ & $12.912 * * *(2.709)$ \\
\hline Sanitation practices ( $1=$ yes, $0=$ otherwise) & $-2.526 * * *(1.048)$ & & \\
\hline Constant & $-1.054(1.271)$ & $2.190(2.543)$ & $2.977(3.458)$ \\
\hline No. of observations & 727 & 1002 & 1002 \\
\hline R-squared & 0.055 & 0.107 & 0.107 \\
\hline F-value & $2.49 * * *$ & $9.72 * * *$ & $9.72 * * *$ \\
\hline
\end{tabular}

Households that consistently participated in training focused on BXW management received significantly higher yields and were better off in terms of welfare than their counterparts who did not receive training. Blomme et al. (2019) asserted that the application of the BXW control package is knowledge intensive. Previous research has shown the importance of these trainings in enhancing adoption of recommended practices (Jogo et al., 2013; Kikulwe et al., 2019) and improving farmers' welfare (Kikulwe et al., 2019). Ocimati et al. (2018) also found that households that had accessed BXW management training were the ones that had effectively controlled the disease on-farm.

The sanitation practices in the banana-productivity model were a combination of de-suckering, de-trashing and weeding and these had a significant negative effect on yield. These findings concur with previous studies, which showed that these practices play a crucial role in influencing disease presence and incidence on farm, especially if they are conducted without cleaning the tools between plants, thus transmitting the pathogens to other plants and resulting into low yields (Blomme et al., 2019; Ocimati, Ssekiwoko, Karamura, Tinzaara, \& Blomme, 2011). To prevent this, hand weeding and use of herbicides have been recommended to minimize the use of tools, as well as 
sterilizing tools between plants whenever they are used (Blomme et al., 2019; Ocimati et al., 2011; Ocimati et al., 2018). On the other hand, productivity increased with bigger farm sizes. These results are consistent with Kikulwe et al. (2019) who found that large farms' value per acre for banana production increased, especially when they adopted all the BXW control practices.

Level of education of the household head and the size of the household also significantly influenced household welfare. This may be because more educated farmers can make better decisions regarding their farm portfolios (Jena et al., 2012) and larger households have more labour available to work on the farms thereby increasing support to farm and disease control activities, which ultimately improves their welfare.

\section{Conclusion}

Banana is an essential crop for the livelihoods of smallholder farmers in ECA yet BXW remains the major constraint to its production. The devastating effects it has caused to farm households in the region have been widely documented. In this article, we have contributed to the literature by analysing the long-term impact of the disease on the welfare of banana-producing households in Uganda, as well as the alternative strategies they pursue to cope with BXW, in addition to adopting the established BXW control practices. Previous adoption studies have overlooked the importance of consistency of application of the control practices. Time and experience have shown that the disease resurged in areas where adoption was sporadic. Our study therefore focused on the systematic adoption of control practices and how it has influenced suppression of disease incidence, and its effect on banana productivity and farmer welfare over time. Empirical analysis was based on a longitudinal study of farming households in the four main banana-growing regions of Uganda that are grappling with BXW. Results reveal that households expanded production of beans and coffee but not at the expense of their banana plantations. Investment in coffee was constrained by land ownership hence only the wealthy farmers could venture into it. Resource-poor farmers continued to capitalize on bananas for their livelihoods. Larger households were more likely to improve their welfare possibly due to availability of labour that they would utilise in conducting the control practices and working in their plantations. The use of tools for de-trashing, de-suckering and weeding in banana plantations needs to be minimal or avoided where possible since these transmit pathogens from one plant to another, unless they are thoroughly disinfected between plants. Consistent participation in training pertinent to disease management significantly influenced adoption of the control practices. Consequently, through systematic adoption of these practices, farming households were able to maintain disease incidence at low levels, improve productivity by $438 \mathrm{~kg} / \mathrm{ha} /$ year, as well as daily and annual household welfare by US $\$ 1.75$ and $\$ 648$, respectively.

Based on these findings, we conclude that banana is an important crop for the farming households in the region, especially among the resource-poor households who depend on it for their livelihood. We noted that technologies that focus on reducing disease incidence levels are likely to have more benefits when targeted towards farmers that consider the crop under context as their main priority. Only wealthy farmers could expand into production of cash crops such as coffee. Availability of labour and consistent farmer training are essential to sustainably increase adoption of the recommended cultural control practices in countries where the disease exists or where it is expected to spread and emerge. Our results confirm that systematic adoption of these practices significantly boosts banana yields and improves the welfare of farming households despite continued exposure to the disease.

We recommend that efforts by research and development institutions focus on developing innovations that are pro-poor and applicable by smallholder farmers. There is need to adapt the technology package to better suit the needs and socio-economic conditions of smallholder farmers through a participatory technology development approach that takes into account research findings, farmers' indigenous knowledge and resource outlays to enhance wider adoption. Farmer outreach through extension and advisory services need to be continuous and consistent. Refresher training courses need to be conducted to keep farmers abreast with the recommended practices.

\section{References}

Bagamba, F., Kikulwe, E., Tushemereirwe, W., Ngambeki, D., Muhangi, J., Kagezi, G., \& Green, S. (2006). Awareness of banana bacterial wilt control in Uganda: 1. Farmers' perspective. African Crop Science Journal, 14(2), 157-164. https://doi.org/10.4314/acsj.v14i2.27923

Biruma, M., Pillay, M., Tripathi, L., Blomme, G., Abele, S., Mwangi, M., .. Nyine, M. (2007). Banana Xanthomonas wilt: a review of the disease, management strategies and future research directions. African Journal of Biotechnology, 6(8). 
Blomme, G., Jacobsen, K., Ocimati, W., Beed, F., Ntamwira, J., Sivirihauma, C., ... Karamura, E. (2014). Fine-tuning banana Xanthomonas wilt control options over the past decade in East and Central Africa. European Journal of Plant Pathology, 139(2), 271-287. https://doi.org/10.1007/s10658-014-0402-0

Blomme, G., Ocimati, W., Sivirihauma, C., Lusenge, V., Bumba, M., \& Ntamwira, J. (2019). Controlling Xanthomonas wilt of banana: Influence of collective application, frequency of application, and social factors on the effectiveness of the Single Diseased Stem Removal technique in eastern Democratic Republic of Congo. Crop Protection, 118, 79-88. https://doi.org/10.1016/j.cropro.2018.12.015

Blomme, G., Ocimati, W., Sivirihauma, C., Vutseme, L., Mariamu, B., Kamira, M., ... Ntamwira, J. (2017). A control package revolving around the removal of single diseased banana stems is effective for the restoration of Xanthomonas wilt infected fields. European Journal of Plant Pathology, 149(2), 385-400. https://doi.org/10.1007/s10658-017-1189-6

Chapoto, A., \& Jayne, T. S. (2008). Impact of AIDS-related mortality on farm household welfare in Zambia. Economic Development and Cultural Change, 56(2), 327-374. https://doi.org/10.1086/522894

Elias, A., Nohmi, M., Yasunobu, K., \& Ishida, A. (2016). Farmers' satisfaction with agricultural extension service and its influencing factors: a case study in North West Ethiopia. Journal of Agricultural Science and Technology, 18(1), 39-53.

Fiedler, J. L., Kikulwe, E. M., \& Birol, E. (2013). An ex ante analysis of the impact and cost-effectiveness of biofortified high-provitamin A and high-iron banana in Uganda (Vol. 1277). Intl Food Policy Res Inst.

Geberewold, A. Z. (2019). Review on impact of banana bacterial wilt (Xhantomonas campestris pv. Musacerum) in East and Central Africa. Cogent Food \& Agriculture, 5(1), 1586075. https://doi.org/10.1080/ 23311932.2019.1586075

Hartje, R., Bühler, D., \& Grote, U. (2018). Eat your fish and sell it, too-livelihood choices of small-scale fishers in Rural Cambodia. Ecological Economics, 154, 88-98. https://doi.org/10.1016/j.ecolecon.2018.07.002

Jena, P. R., Chichaibelu, B. B., Stellmacher, T., \& Grote, U. (2012). The impact of coffee certification on small-scale producers' livelihoods: A case study from the Jimma Zone, Ethiopia. Agricultural Economics, 43(4), 429-440. https://doi.org/10.1111/j.1574-0862.2012.00594.x

Jogo, W., Karamura, E., Tinzaara, W., Kubiriba, J., \& Rietveld, A. (2013). Determinants of farm-level adoption of cultural practices for Banana Xanthomonas wilt control in Uganda. Journal of Agricultural Science, 5(7), 70. https://doi.org/10.5539/jas.v5n7p70

Kabahenda, M., \& Kapiriri, M. (2010). Analysing the agricultural science and technology innovation systems: A case study of the banana sub-sector in Uganda. Paper presented at the Technical Centre for Agricultural and Rural Cooperation (CTA) and Regional Universities Forum for Capacity Building in Agriculture (RUFORUM).

Kalyebara, M., Ragama, P., Kikulwe, E., Bagamba, F., Nankinga, K., \& Tushemereirwe, W. (2006). Economic importance of the banana bacterial wilt in Uganda. African Crop Science Journal, 14(2), 93-103. https://doi.org/10.4314/acsj.v14i2.27915

Karamura, E., Kayobyo, G., Tushemereirwe, W., Benin, S., Blomme, G., Eden Green, S., \& Markham, R. (2010). Assessing the Impacts of Banana Bacterial Wilt Disease on banana bacterial wilt disease on banana (Musa spp.) productivity and livelihoods of Ugandan farm households. Paper presented at the IV International Symposium on Banana: International Conference on Banana and Plantain in Africa: Harnessing International. https://doi.org/10.17660/ActaHortic.2010.879.81

Karamura, E., Turyagyenda, F., Tinzara, W., Blomme, G., Ssekiwoko, F., Eden-Green, S., ... Markham, R. (2008). Xanthomonas wilt of bananas in East and Central Africa. Diagnostic and Management Guide (pp. 978-982). Bioversity International, Uganda.

Kayobyo, G., Aliguma, L., Omiat, G., Mugisha, J., \& Benin, S. (2005). Impact of BXW on household livelihoods in Uganda. Assessing the impact of the banana bacterial wilt.

Kikulwe, E. M., Kyanjo, J. L., Kato, E., Ssali, R. T., Erima, R., Mpiira, S., ... Gotor, E. (2019). Management of Banana Xanthomonas Wilt: Evidence from Impact of Adoption of Cultural Control Practices in Uganda. Sustainability, 11(9), 2610. https://doi.org/10.3390/su11092610

Kikulwe, E. M., Okurut, S., Ajambo, S., Gotor, E., Ssali, R. T., Kubiriba, J., \& Karamura, E. (2018). Does gender matter in effective management of plant disease epidemics? Insights from a survey among rural banana 
farming households in Uganda. Journal of Development and Agricultural Economics, 10(3), 87-98. https://doi.org/10.5897/JDAE2017.0877

Kikulwe, E. M., Okurut, S., Ajambo, S., Nowakunda, K., Stoian, D., \& Naziri, D. (2018). Postharvest losses and their determinants: A challenge to creating a sustainable cooking banana value chain in Uganda. Sustainability, 10(7), 2381. https://doi.org/10.3390/su10072381

Kilimo Trust. (2012). Banana Value Chain(s) in the EAC: Consumption, productivity and challenges. Kilimo Trust, Kampala, Uganda.

Kubiriba, J., \& Tushemereirwe, W. (2014). Approaches for the control of banana Xanthomonas wilt in East and Central Africa. African Journal of Plant Science, 8(8), 398-404. https://doi.org/10.5897/AJPS2013.1106

Mehar, M., Mittal, S., \& Prasad, N. (2016). Farmers coping strategies for climate shock: is it differentiated by gender? Journal of Rural Studies, 44, 123-131. https://doi.org/10.1016/j.jrurstud.2016.01.001

Muchuruza, Y. P., \& Melchior, H. R. (2013). The effects of Banana Xanthomonas Wilt (BXW) on food security and the people's livelihood: The case of Nshamba and Rubale divisions in Kagera Region. Centre for Development Initiatives.

Mwangi, M., Nakato, V., \& Muthoni, S. (2007). Methods for Disinfecting Tools in Management of Banana Xanthomonas Wilt Disease. Paper presented at the 8th African Crop Science Society Conference, El-Minia, Egypt, 27-31 October 2007.

Nakakawa, J., Mugisha, J. Y., Shaw, M. W., Tinzaara, W., \& Karamura, E. (2017). Banana Xanthomonas wilt infection: The role of debudding and roguing as control options within a mixed cultivar plantation. International Journal of Mathematics and Mathematical Sciences, 2017. https://doi.org/10.1155/2017/ 4865015

Nguyen, T.-T., Nguyen, T. T., \& Grote, U. (2020). Multiple shocks and households' choice of coping strategies in rural Cambodia. Ecological Economics, 167, 106442. https://doi.org/10.1016/j.ecolecon.2019.106442

Nkuba, J., Tinzaara, W., Night, G., Niko, N., Jogo, W., Ndyetabula, I., ... Gaidashova, S. (2015). Adverse impact of Banana Xanthomonas wilt on farmers livelihoods in Eastern and Central Africa. African Journal of Plant Science, 9(7), 279-286. https://doi.org/10.5897/AJPS2015.1292

Ocimati, W., Bouwmeester, H., Groot, J. C., Tittonell, P., Brown, D., \& Blomme, G. (2019). The risk posed by Xanthomonas wilt disease of banana: Mapping of disease hotspots, fronts and vulnerable landscapes. PloS ONE, 14(4), e0213691. https://doi.org/10.1371/journal.pone.0213691

Ocimati, W., Ssekiwoko, F., Karamura, E., Tinzaara, W., \& Blomme, G. (2011). Does Xanthomonas campestris pv. musacearum colonize banana cord root tissue? Paper presented at the VII International Symposium on Banana: ISHS-ProMusa Symposium on Bananas and Plantains: Towards Sustainable Global Production 986.

Ocimati, W., Were, E., Groot, J. C., Tittonell, P., Nakato, G. V., \& Blomme, G. (2018). Risks posed by intercrops and weeds as alternative hosts to Xanthomonas campestris pv. musacearum in banana fields. Frontiers in Plant Science, 9, 1471. https://doi.org/10.3389/fpls.2018.01471

Smith, J., Jones, D., Karamura, E., Blomme, G., \& Turyagyenda, F. (2008). An analysis of the risk from Xanthomonas campestris pv. musacearum to banana cultivation in Eastern, Central and Southern Africa. ProMusa. Retreived from http://www.promusa.org/index.php?option=com_content\&task=view\&id=66

Ssewanyana, S., \& Kasirye, I. (2013). The dynamics of income poverty in Uganda: Insights from the Uganda National Panel Surveys of 2009/10 and 2010/11. EPRC Occasional Papers.

Tripathi, L., Mwangi, M., Abele, S., Aritua, V., Tushemereirwe, W. K., \& Bandyopadhyay, R. (2009). Xanthomonas wilt: a threat to banana production in East and Central Africa. Plant Disease, 93(5), 440-451. https://doi.org/10.1094/PDIS-93-5-0440

Tushemereirwe, W., Kangire, A., Ssekiwoko, F., Offord, L., Crozier, J., Boa, E., ... Smith, J. (2004). First report of Xanthomonas campestris pv. musacearum on banana in Uganda. Plant Pathology, 53(6), 802-802. https://doi.org/10.1111/j.1365-3059.2004.01090.x

Tushemereiwe, W., Okaasai, O., Kubiriba, J., Nankinga, C., Muhangi, J., Odoi, N., \& Opio, F. (2006). Status of banana bacterial wilt in Uganda. African Crop Science Journal, 14(2), 73-82. https://doi.org/10.4314/ acsj.v14i2.27913

UBOS. (2014). Uganda National Household Survey 2012/2013. Kampala, Uganda. 
UBOS. (2019). Statistical Abstract 2018: Uganda Bureau of Statistics. Kampala, Uganda.

Uwamahoro, F., Berlin, A., Bylund, H., Bucagu, C., \& Yuen, J. (2019). Management strategies for banana Xanthomonas wilt in Rwanda include mixing indigenous and improved cultivars. Agronomy for Sustainable Development, 39(2), 1-11. https://doi.org/10.1007/s13593-019-0569-Z

Vezina, A. (2014). Rehabilitating banana fields devastated by Xanthomonas wilt. ProMusa. Retrieved from http:/www.promusa.org/blogpost356-Rehabilitating-banana-fields-devastated-by-Xanthomonas-wilt

Wooldridge, J. M. (2002). Econometric analysis of cross section and panel data MIT press (P. 108). Cambridge, MA.

World Bank. (2008). Agriculture for Development. Washington DC: The International Bank for Reconstruction and Development/The World Bank.

\section{Copyrights}

Copyright for this article is retained by the author(s), with first publication rights granted to the journal.

This is an open-access article distributed under the terms and conditions of the Creative Commons Attribution license (http://creativecommons.org/licenses/by/4.0/). 